\title{
Grafik Penentuan Komposisi Campuran Agregat Material Pengaspalan Jalan Memanfaatkan Metode Digital Differential Analyzer (DDA)
}

\author{
Anisya \\ Program Studi Teknik Informatika, Fakultas Teknologi Industri, Institut Teknologi Padang \\ nisya@itp.ac.id
}

\begin{abstract}
The more advanced technology can make it easier for someone to do their work. Included in it in terms of making graphics that can be done using computer assistance. Where computers can represent human work functions. This study aims to create an application graph for the determination of the composition of the aggregate mixture and provide the results of the calculation of the percentage of each aggregate and provide recommendations whether the composition of the aggregate mixture is feasible or not to be used. The results of this study are a graphical application for determining the value of the composition of the aggregate mixture. This application has been tested using DOSBox and TURBO C ++. Based on the results of these trials it can be concluded that the application of graphs to determine the value of aggregate mixture composition can be used as a tool for making graphs of aggregate mixtures and determining the value of aggregate composition and providing recommendations in the form of recommendations.
\end{abstract}

Keywords: Graph, DDA Method (Digital Differential Analyzer), Aggregate, Computer Graphic.

\begin{abstract}
Abstrak
Semakin majunya teknologi maka dapat mempermudah seseorang melakukan pekerjaannya. Termasuk didalamnya dalam hal pembuatan grafik yang bisa dilakukan dengan menggunakan bantuan komputer. Dimana komputer dapat mewakili fungsi kerja manusia. Penelitian ini bertujuan untuk membuat sebuah aplikasi grafik penentuan komposisi campuran agregat dan memberikan hasil kalkulasi persentase masing-masing agregat beserta memberikan rekomendasi apakah komposisi campuran agregat layak atau tidak untuk digunakan. Hasil penelitian ini adalah sebuah aplikasi grafik untuk penentuan nilai komposisi campuran agregat. Aplikasi ini telah diuji coba dengan menggunakan DOSBox dan TURBO C++. Berdasarkan hasil uji coba tersebut dapat disimpulkan bahwa aplikasi grafik penentuan nilai komposisi campuran agregat ini dapat digunakan sebagai alat bantu untuk pembuatan grafik campuran agregat beserta penentuan nilai komposisi agregat dan memberikan masukan berupa rekomendasi.
\end{abstract}

Kata Kunci: Grafik, Metode DDA(Digital Differential Analyzer), Agregat, Grafika Komputer.

\section{PENDAHULUAN}

Di setiap negara membutuhkan fasilitas-fasilitas publik untuk mendukung setiap aktivitas di negaranya. Terutama kebutuhan akan pembangunan jalan dan jembatan yang digunakan untuk sarana transportasi. Tingkat kebutuhan akan pembangunan jalan di setiap negara seperti Indonesia selalu meningkat setiap tahunnya. Seiring dengan hal tersebut, maka kebutuhan akan pembangunan jalan dan perbaikan akan jalan yang rusak itu sendiri juga meningkat. Hal ini tidak bisa terlepas akan kebutuhan material penyusun pengaspalan jalan. Adapun bahan penyusun lapisan permukaan pengaspalan jalan terdiri atas campuran agregat kasar, agregat halus, bahan pengisi dan aspal. Adapun yang dimaksud dengan agregat kasar 
adalah agregat dengan ukuran butir antara 5-40 mm. Sedangkan agregat halus adalah agregat dengan ukuran butir paling besar $5 \mathrm{~mm}$ seperti pasir [14].

Adapun komposisi campuran agregat untuk pembuatan jalan seperti agregat kasar, agregat halus dan bahan pengisi ditentukan berdasarkan bentuk grafik yang dihasilkan. Adapun metode yang digunakan untuk mencari nilai komposisi campuran agregat tersebut menggunakan metode diagonal, dimana bentuk grafik yang akan dihasilkan bergantung kepada nilai persentase lolos material masing-masing agregat. Adapun proses pembuatan grafik dan pencarian nilai komposisi campuran agregat untuk material pengaspalan jalan ini membutuhkan ketelitian yang tinggi dan memiliki tingkat kerumitan yang tinggi pula sehingga membutuhkan waktu yang lama dalam proses pembuatannya dan oleh karena itu dibutuhkan sebuah aplikasi yang berguna untuk mempermudah pembuatan grafik yang diinginkan dan sekaligus mencari nilai komposisi campuran agregat untuk material pengaspalan jalan tersebut dengan cara yang lebih cepat dan mudah. Dan dapat diselesaikan dalam waktu yang singkat.

Dalam pembuatan grafik tersebut digunakan metode DDA dalam pembuatan garisnya. Tujuan menggunakan metode DDA dalam pembuatan garis pada grafik tersebut adalah untuk melihat kemampuan metode DDA dalam membuat garis sekaligus melihat seberapa presisi kemampuan algoritma DDA dalam pembuatan garis tersebut. Kemudian lebih mudah diterapkan dan tidak menggunakan biaya tambah untuk membeli libararynya. Dari latar belakang tersebut maka penulis tertarik untuk membuat sebuah aplikasi yang akan mempermudah pencarian nilai komposisi untuk masing-masing campuran agregat untuk campuran material pengaspalan jalan dan memudahkan pembuatan grafik hasil pencarian tersebut dengan judul "Grafik penentuan komposisi campuran agregat untuk campuran material pengaspalan jalan menggunakan metode DDA(Digital Differential Analizer)".

\section{METODOLOGI PENELITIAN}

Handayaningsih membahas tentang penggunaan algoritma garis, termasuk di dalamnya Metode DDA yang berbasis multimedia. Dimana dalam jurnal ini membahas tentang pembentukan garis dengan Metode DDA berdasarkan nilai perhitungan $\mathrm{dx}\left(x_{2}-x_{1}\right)$ dan $\mathrm{dy}\left(y_{2}-y_{1}\right)$ [8]. Ipte membahas tentang kelebihan dan kekurangan algoritma-algoritma pembuatan garis dan lingkaran secara efisien. Termasuk di dalamnya kelebihan dan kekurangan algoritma DDA. Dimana kelebihan algoritma DDA yang dikemukakannya adalah dapat bekerja lebih cepat dari pada menggunakan persamaan garis secara langsung dan dapat mengurangi jumlah penggandaan nilai titik (menghasilkan nilai titik yang sama) dan pengambangan nilai titik pada pembuatan garis[10].

Trivedi dengan penelitiannya yang membahas tentang simulasi pembuatan garis menggunakan Metode DDA. Dimana garis dihasilkan dengan menghitung koordinat titik tengah antara dua titik yang ditentukan 
(antara titik awal dan akhir). Posisi piksel yang akan digambar diposisikan pada titik yang terletak sangat dekat dengan jalur garis yang akan digambar[18].

\subsection{Pengertian Grafik}

Grafik adalah penyajian data yang terdapat dalam tabel yang ditampilkan ke dalam bentuk gambar. Selain itu grafik juga dapat diartikan sebagai suatu kombinasi data-data baik berupa angka, huruf, simbol, gambar, lambang, perkataan, lukisan, yang disajikan dalam sebuah media dengan tujuan memberikan gambaran tentang suatu data dari penyaji materi kepada para penerima materi dalam proses menyampaikan informasi[4].

\subsection{Agregat}

Agregat adalah material granular, misalnya pasir, kerikil, batu pecah yang dipakai bersama-sama dengan suatu media pengikat untuk membentuk suatu beton semen hidraulik atau adukan [15]. Agregat merupakan butir-butir batu pecah, kerikil, pasir atau mineral lain, baik yang berasal dari alam maupun buatan yang berbentuk mineral padat berupa ukuran besar maupun kecil atau fragmen-fragmen [17]. Agregat merupakan komponen utama dari struktur perkerasan jalan, yaitu 90\% - 95\% agregat berdasarkan persentase berat, atau $75-85 \%$ agregat berdasarkan persentase volume.

\subsection{Metode DDA (Digital Differential Analyzer)}

DDA adalah algoritma pembentukan garis berdasarkan perhitungan $\mathrm{dx}$ maupun dy. Garis dibuat dengan menentukan dua endpoint, yaitu titik awal dan titik akhir. Setiap koordinat titik yang membentuk garis diperoleh dari perhitungan, kemudian dikonversikan menjadi nilai integer [8]. Metode Digital Differential Analyzer (DDA) banyak digunakan untuk merencanakan jalur robot mobile. Dalam perencanaan jalur robot bergerak, para peneliti menggunakan banyak algoritma untuk optimisasi dan DDA adalah salah satunya dan dianggap sebagai sasaran metode lain [7].

Algoritma DDA mengambil nilai integer terdekat dengan jalur garis berdasarkan atas sebuah titik yang telah ditentukan sebelumnya (titik awal garis). Keuntungan dari algoritma ini adalah tidak perlu menghitung koordinat berdasarkan persamaan yang lengkap (menggunakan metode offset). Keuntungan utama dari DDA adalah presisi yang lebih besar dari hasil dan kurangnya drift / noise / slip / lash dalam perhitungan. Presisi ini hanya dibatasi oleh ukuran register dan hasil accumulated rounding, yang mengakibatkan kesalahan pemotongan / penambahan berulang. Untuk masalah yang dapat dinyatakan sebagai persamaan diferensial, sebuah DDA dapat menyelesaikannya lebih cepat daripada general purpose computer seperti personal computer (menggunakan teknologi serupa).

\subsection{Metode Pengumpulan Data}

Metode ini digunakan dengan cara membaca jurnal dan buku-buku literature/referensi yang berkaitan dengan Grafika Komputer dan Algoritma 
DDA seperti diktat Grafika Komputer serta mempelajari laporan-laporan dan buku-buku lain yang berkaitan dengan penelitian.

\subsection{Metode Membuat Garis}

Untuk menggambarkan algoritma DDA dalam pembentukan suatu garis yang menghubungkan titik $(10,10)$ dan $(17,16)$, pertama-tama ditentukan $\mathrm{dx}$ dan dy, kemudian dicari step untuk mendapatkan $x_{-}$increment dan $y_{-}$increment.

$$
\begin{aligned}
& d x=x_{1}-x_{0}=17-10=7 \\
& d y=y_{1}-y_{0}=16-10=6
\end{aligned}
$$

selanjutnya hitung dan bandingkan nilai absolutnya.

$$
\begin{aligned}
& |d x|=7 \\
& |d y|=6
\end{aligned}
$$

karena $|\mathrm{dx}|>|\mathrm{dy}|$, maka step $=|\mathrm{dx}|=7$, maka diperoleh :

$$
\begin{aligned}
& \text { x_inc }=7 / 7=1 \\
& \text { y_inc }=6 / 7=0,86 .
\end{aligned}
$$

\begin{tabular}{|c|c|c|c|}
\hline $\mathbf{k}$ & $\mathbf{x}$ & $\mathbf{y}$ & round(x),round(y) \\
\hline & & & $(10,10)$ \\
\hline 0 & 11 & 10,86 & $(11,11)$ \\
\hline 1 & 12 & 11,72 & $(12,12)$ \\
\hline 2 & 13 & 12,58 & $(13,13)$ \\
\hline 3 & 14 & 13,44 & $(14,13)$ \\
\hline 4 & 15 & 14,3 & $(15,14)$ \\
\hline 5 & 16 & 15,16 & $(16,15)$ \\
\hline 6 & 17 & 16,02 & $(17,16)$ \\
\hline
\end{tabular}

Gambar 1. Hasil Perhitungan DDA

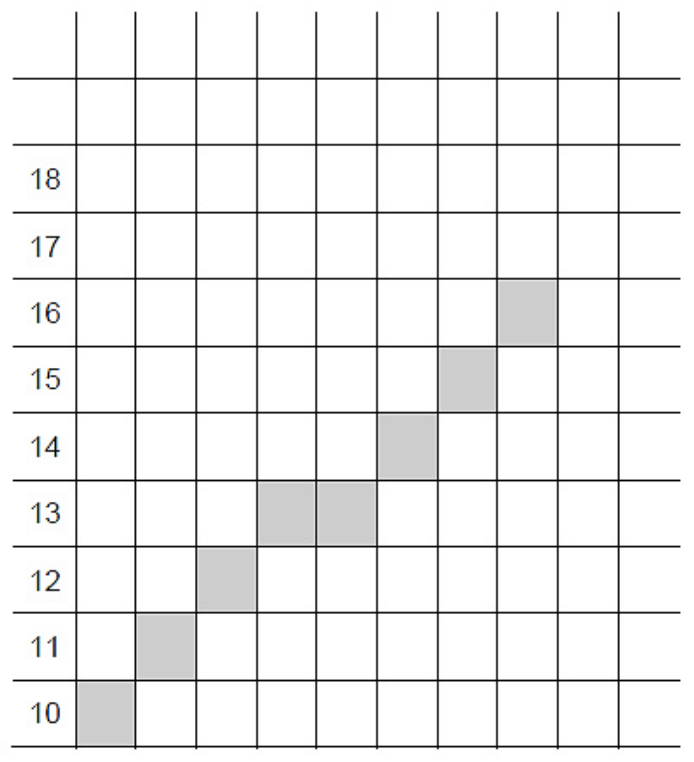

$\begin{array}{lllllllll}10 & 11 & 12 & 13 & 14 & 15 & 16 & 17 & 18\end{array}$

Gambar 2. Hasil Penggambaran Pixel Garis 


\subsection{Tahapan Pembuatan Grafik}

Adapun tahapan dalam pembuatan grafik adalah sebagai berikut:

a. Buat nilai ukuran ayakan sebagai sumbu $\mathrm{x}$, dimana nilai yang digambarkan 10 kali dari nilai yang sebenarnya.

b. Buat nilai persentase lolos sebagai sumbu y dari 0-100 dengan jarak 10 .

c. Buatlah garis vertikal dari nilai ukuran ayakan ke batas atas nilai persentase lolos.

d. Menentukan posisi titik-titik penggambaran nilai ukuran ayakan dan nilai persentase $\operatorname{lolos}(\mathrm{x}, \mathrm{y})$.

e. Kemudian hubungkan titik-titik tersebut dengan menggunakan algoritma DDA untuk membuat kurva satu nilai material.

f. Lakukan langkah 4-5 untuk material selanjutnya

g. Buatlah nilai ukuran ayakan sebagai sumbu $\mathrm{x}$ dan nilai spesifikasi minimum sebagai sumbu y sehingga terbentuk titik $(x, y)$

h. Hubungkan setiap titik $(\mathrm{x}, \mathrm{y})$ dengan menggunakan algortitma DDA untuk setiap nilai spesifikasi minimum.

i. Lakukan langkah 7-8 untuk setiap nilai spesifikasi ideal dan spesifikasi maksimum.

j. Cerminkan kurva material 1 terhadap sumbu $\mathrm{x}$ dan cari titik potongnya terhadap material 2.

k. Hubungkan titik potongnya ke garis diagonal (spesifikasi ideal) dan hubungkan ke sumbu y.

l. Akan didapatkan nilai persentase campuran agregat material 1 .

m. Lakukan langkah 10-11 untuk mendapatkan nilai persentase selanjutnya dikurangi persentase sebelumnya.

n. Nilai persentase campuran agregat yang terakhir diperoleh dari hasil $100 \%$-(Nilai persentase campuran agregat sebelumnya).

Misal : $\quad$ Persentase Material $\mathrm{A}=10 \%$

Persentase Material $\mathrm{B}=45 \%$

Persentase Material C $=100 \%-(10 \%+45 \%)=45 \%$.

Rumus mencari titik potong antara kurva material 1 dan 2 :

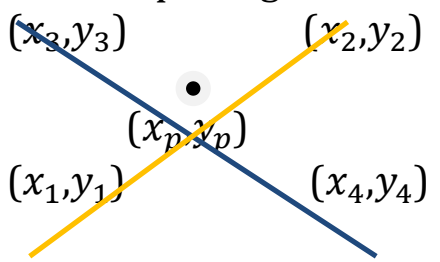

Diketahui nilai $\left(x_{1}, y_{1}\right),\left(x_{2}, y_{2}\right),\left(x_{3}, y_{3}\right)$ dan $\left(x_{4}, y_{4}\right)$ serta mencari nilai (xp,yp). $m_{1}=\frac{d y}{d x}=\frac{\left(y_{2}-y_{1}\right)}{\left(x_{2}-x_{1}\right)}$

$m_{3}=\frac{d y}{d x}=\frac{\left(y_{4}-y_{3}\right)}{\left(x_{4}-x_{3}\right)}$

$y_{1}=m_{1} x_{1}+c_{1}$

$c_{1}=y_{1}-m_{1} x_{1}$

$y_{3}=m_{3} x_{3}+c_{3}$

$c_{3}=y_{3}-m_{3} x_{3}$ 
Pada saat kedua titik berpotongan pada $\left(x_{p}, y_{p}\right)$, maka $\left(x_{1}, y_{1}\right)$ dan $\left(x_{3}, y_{3}\right)$ adalah sama sehingga persamaan menjadi :

$y_{p}=m_{1} x_{p}+c_{1}$

$y_{p}=m_{3} x_{p}+c_{3}$

Substitusi persamaan 6 ke persamaan 5 , sehingga diperoleh :

$m_{3} x_{p}+c_{3}=m_{1} x_{p}+c_{1}$

$m_{3} x_{p}-m_{1} x_{p}=c_{1}-c_{3}$

$\left(m_{3}-m_{1}\right) x_{p}=c_{1}-c_{3}$

$x_{p}=\frac{\left(c_{1}-c_{3}\right)}{\left(m_{3}-m_{1}\right)}$

Keterangan :

$c_{1}$ diperoleh dari persamaan 3

$c_{3}$ diperoleh dari persamaan 4

$m_{1}$ diperoleh dari persamaan 1

$m_{3}$ diperoleh dari persamaan 2

Berdasarkan nilai $\left(x_{p}, y_{p}\right)$, ditarik garis lurus sejajar sumbu y sehingga memotong garis diagonal(spesifikasi ideal) sehingga diperoleh :

Keterangan : Nilai dari $x_{p}$ dan $x_{t}$ adalah sama.

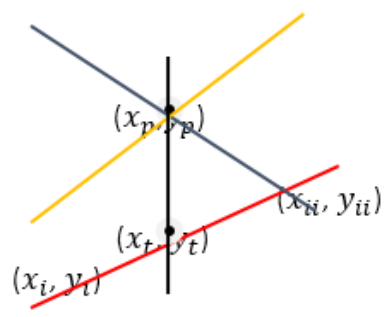

Diketahui nilai dari $\left(x_{i}, y_{i}\right)$ dan nilai dari $\left(x_{i i}, y_{i i}\right)$. Dicari nilai $y_{t}=\ldots$. ??

$m_{\text {Ideal }}=\frac{d y}{d x}=\frac{\left(y_{i i}-y_{i}\right)}{\left(x_{i i}-x_{i}\right)}$

$m_{\text {Ideal }}=\frac{d y}{d x}=\frac{\left(y_{t}-y_{i}\right)}{\left(x_{t}-x_{i}\right)}$

$m_{\text {Ideal }}\left(x_{t}-x_{i}\right)=y_{t}-y_{i}$

$y_{t}-y_{i}=m_{\text {Ideal }}\left(x_{t}-x_{i}\right)$

$y_{t}=m_{\text {Ideal }}\left(x_{t}-x_{i}\right)+y_{i}$

Keterangan :

$x_{t}$ sama dengan $x_{p}$ (karena sejajar sumbu y, garis vertikal)

$m_{\text {Ideal }}$ diperoleh dari persamaan 8

$\left(x_{i}, y_{i}\right)$ adalah nilai yang telah diketahui

\subsection{Bahasa Pemrograman}

Bahasa Pemrograman $\mathrm{C}++$ adalah sebuah bahasa yang diciptakan oleh Bjarne Stroustrup di AT\&T Bell Laboratories awal tahun 1980-an berdasarkan C ANSI(American National Standart Institute). Tanda ++ menunjukkan bahwa bahasa $\mathrm{C}++$ ini merupakan versi yang lebih canggih dari C. Borland International merilis compiler Borland $\mathrm{C}++$ dan Turbo $\mathrm{C}++$. Keduanya sama-sama dapat digunakan untuk kompilasi kode $\mathrm{C}++$ namun 
perbedaannya adalah Borland $\mathrm{C}++$ dapat digunakan untuk pemrograman Windows selain juga dapat digunakan di lingkungan DOS[2].

\section{HASIL DAN PEMBAHASAN}

Contoh file masukan ke dalam program adalah sebagai berikut :

Tabel 1. Contoh Masukan Aplikasi

\begin{tabular}{ccccccccc}
\hline & \multicolumn{2}{c}{ Ayakan } & \multicolumn{3}{c}{ \% Lolos } & \multicolumn{3}{c}{ Spesifikasi } \\
\hline No & $\begin{array}{c}\text { No/Inc } \\
\text { (ASTM) }\end{array}$ & $(\mathrm{Mm})$ & A & B & C & Min & Ideal & Max \\
\hline 1 & 2 & 50.000 & 100 & 100 & 100 & 100 & 100 & 100 \\
2 & 1.5 & 37.800 & 100 & 100 & 100 & 95 & 97.5 & 100 \\
3 & $3 / 4$ & 20.000 & 100 & 100 & 47 & 45 & 62.5 & 80 \\
4 & $3 / 16$ & 5.000 & 82 & 72 & 0 & 25 & 37.5 & 50 \\
5 & 30 & 2.380 & 45 & 24 & 0 & 8 & 19 & 30 \\
6 & 100 & 1.190 & 10 & 9 & 0 & 0 & 4 & 8 \\
\hline
\end{tabular}

Keterangan :

A adalah Material Pasir

B adalah Agregat dengan ukuran 1-2cm

$\mathrm{C}$ adalah Agregat dengan ukuran $2-3 \mathrm{~cm}$

Implementasi aplikasi grafik penentuan komposisi campuran agregat untuk campuran material pengaspalan jalan adalah sebagai berikut :

\subsection{Tampilan Halaman Awal}

Pada tampilan halaman awal terlihat ada dua cara untuk memasukkan data ke dalam program, yaitu secara manual atau dengan menggunakan file excel. Jika pengguna ingin memasukkan data secara manual maka program akan meminta ukuran grafik yang akan digambar.
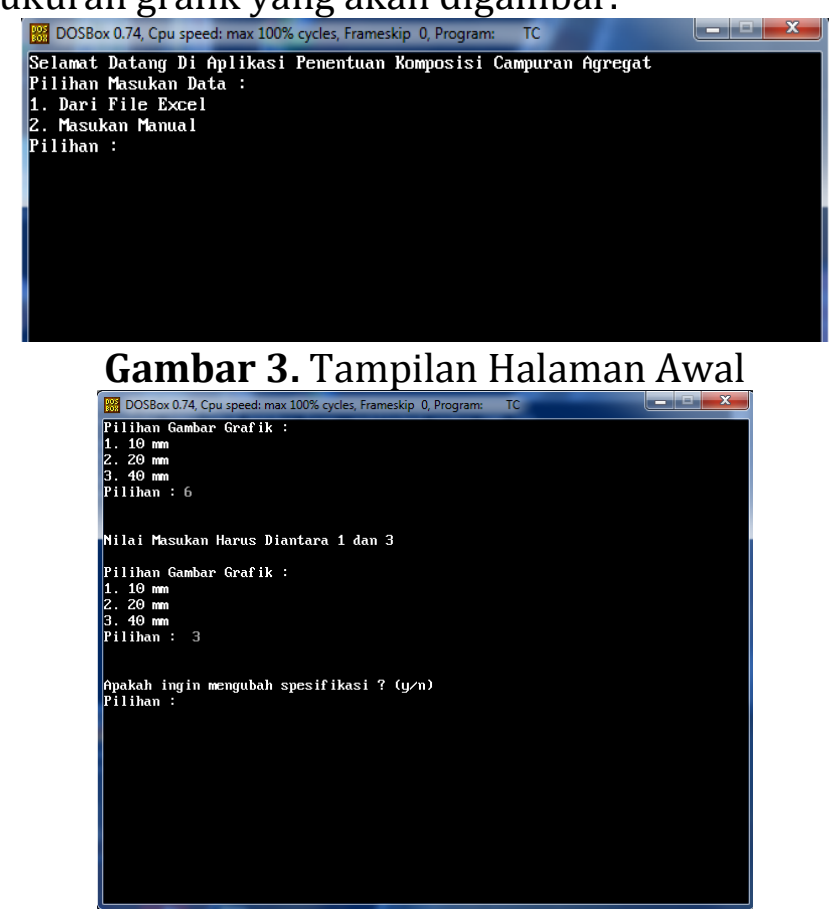

Gambar 4. Halaman Pilihan Ukuran Grafik 
Pada halaman ukuran grafik terdapat 3 pilihan, pilihan pertama untuk menggambar grafik dengan ukuran ayakan maksimal $10 \mathrm{~mm}$, pilihan kedua dengan ukuran $20 \mathrm{~mm}$, dan ketiga dengan ukuran $40 \mathrm{~mm}$.

\subsection{Tampilan Halaman Nilai Ayakan}

Jika telah memilih ukuran grafik, program akan meminta masukan berupa pilihan ya atau tidak untuk mengubah spesifikasi. Jika ya maka program akan meminta masukan nilai ayakan. Nilai masukan sesuai dengan tabel 1, dimana nama ayakan terletak pada kolom No/Inch dan ukuran ayakan terdapat pada kolom (Mm).

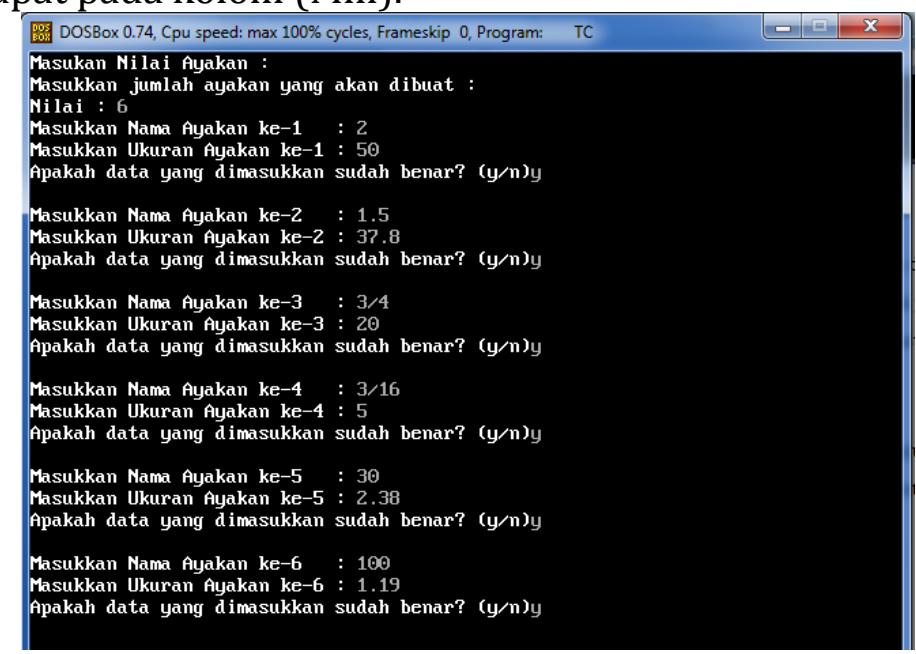

Gambar 5. Tampilan Nilai Ayakan

\subsection{Tampilan Halaman Spesifikasi}

Jika telah mengisi nilai ayakan, maka program akan meminta untuk mengisi nilai spesifikasi minimum dan maksimum, seperti yang tercantum pada tabel 1, dimana nilai yang dimasukkan sesuai dengan ukuran saringannya.

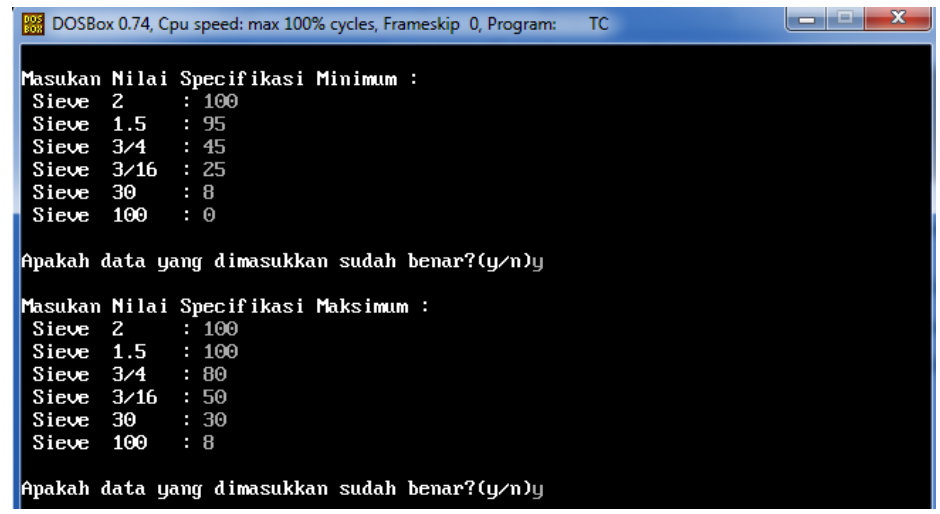

Gambar 6. Tampilan Halaman Spesifikasi

\subsection{Tampilan Halaman Nilai Persentase Lolos Material}

Jika telah mengubah atau memasukkan spesifikasi, maka program selanjutnya akan meminta masukan berupa persentase lolos material. Dimana pada tabel 1, nilai persentase lolos material berada pada kolom 
\%Lolos dengan Nilai A, B dan C adalah nama material yang akan dimasukkan. Dan nilai pada kolom tersebut dimasukkan berdasarkan ukuran saringannya.

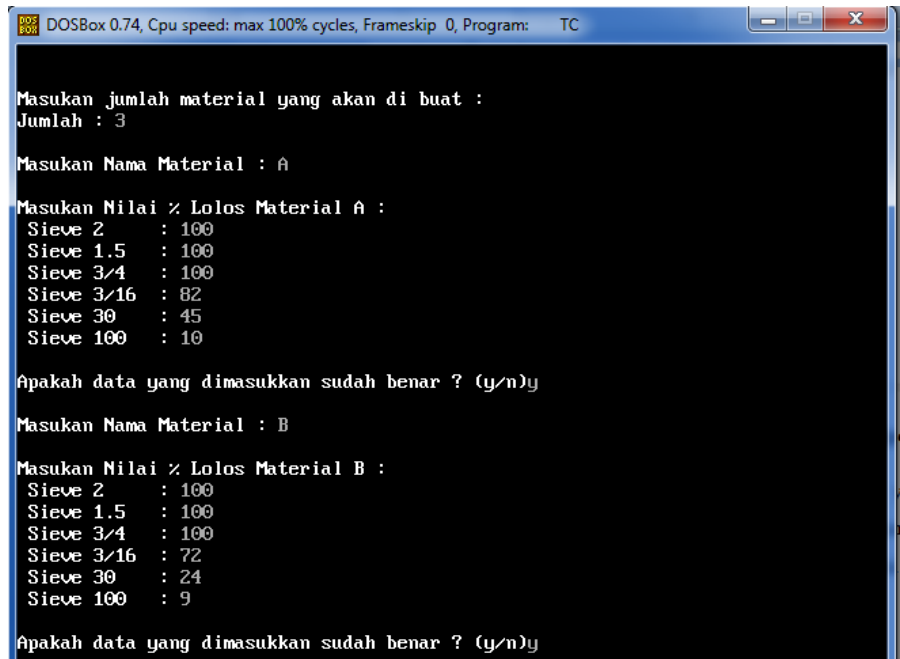

Gambar 7. Halaman Masukan Nilai Persentase Lolos Material

\subsection{Hasil Pengujian Tampilan Grafik}

Setelah memasukkan data ke dalam program baik dengan menggunakan file excel maupun dengan cara manual maka program akan melanjutkannya dengan menggambarkan grafik sesuai dengan masukan yang telah dimasukkan tersebut.

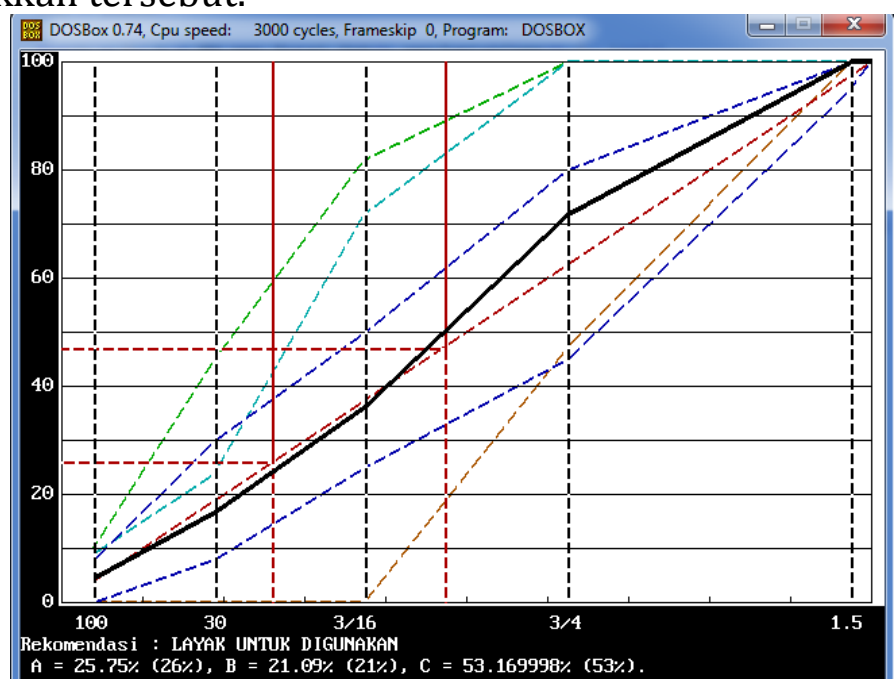

Gambar 8. Hasil Pengujian Tampilan Grafik

Dengan nilai persentase terlihat pada bagian bawah grafik. Dengan $\mathrm{A}=$ $25.75 \%, \mathrm{~B}=21.09 \%$ dan $\mathrm{C}=53.17 \%$. Dengan penjelasan bahwa A adalah nilai untuk material Pasir dengan persentase 25.75\%, B adalah nilai untuk agregat $1-2 \mathrm{~cm}$ dengan persentase $21.09 \%$ dan $\mathrm{C}$ adalah nilai untuk agregat 2-3 cm dengan persentase $53.17 \%$.

\subsection{Hasil Pengujian Grafik dengan Rekomendasi Tidak Layak}

Adapun contoh tabel masukan untuk menghasilkan nilai grafik dengan rekomendasi tidak layak adalah sebagai berikut : 
Tabel 2. Contoh Masukan Nilai Tidak Layak

\begin{tabular}{cccccccc}
\hline & \multicolumn{2}{c}{ Ayakan } & \multicolumn{2}{c}{ \% Lolos } & \multicolumn{3}{c}{ Spesifikasi } \\
\hline No & $\begin{array}{c}\text { No/Inc } \\
\text { (ASTM) }\end{array}$ & $(\mathrm{Mm})$ & A & B & Min & Ideal & Max \\
\hline 1 & 1.5 & 37.500 & 100 & 100 & 100 & 100 & 100 \\
2 & $3 / 4$ & 20.000 & 100 & 96 & 95 & 97.5 & 100 \\
3 & $3 / 16$ & 4.750 & 100 & 4 & 35 & 45 & 55 \\
4 & 30 & 0.600 & 98 & 0 & 10 & 22.5 & 35 \\
5 & 100 & 0.150 & 3 & 0 & 0 & 4 & 8 \\
\hline
\end{tabular}

Adapun hasil tampilan grafik dengan masukan menggunakan nilai tabel 2 adalah sebagai berikut :

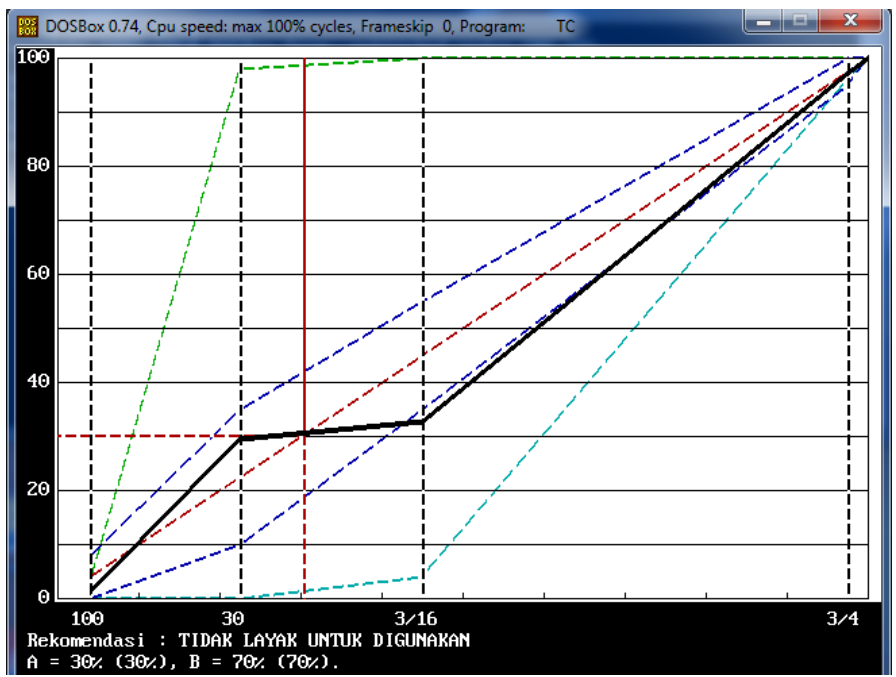

Gambar 9. Grafik dengan Rekomendasi Tidak Layak

Dari gambar di atas dapat dilihat bahwa garis hitam tebal yang merupakan garis total gabungan berada dibawah garis spesifikasi minimum. Sehingga program mengeluarkan rekomendasi tidak layak untuk digunakan. Dengan nilai persentase terlihat pada bagian bawah grafik. Dengan A $=30 \%$ dan $\mathrm{B}=70 \%$. Dengan penjelasan bahwa $\mathrm{A}$ adalah nilai untuk material Pasir dengan persentase $30 \%$ dan $B$ adalah nilai untuk Koral dengan persentase 70 $\%$.

\section{SIMPULAN}

Aplikasi yang telah dibuat dapat membantu dalam hal melakukan pencarian komposisi campuran agregat untuk campuran material pengaspalan jalan dengan cara yang lebih singkat dan mudah. Serta dapat membuat grafik hasil pencarian komposisi agregat sehingga tidak perlu menggambar grafik secara manual. Hasil penggambaran grafik yang dihasilkan dalam komputer dapat diterapkan dalam pembuatan atau pemeliharaan jalan. Dari grafik yang akan dihasilkan akan terlihat gambaran grafik campuran agregat untuk campuran material pengaspalan jalan apakah dapat diterima untuk dilakukan pembuatan jalan atau tidak. 


\section{DAFTAR PUSTAKA}

[1] Al-Muqarramah. (2012). Rancangan Campuran Aspal. Dipetik Mei 16, 2018, dari http://cyber007-cyber.blogspot.com/2012/02/rancangan-campuranaspal.html

[2] Ambarsari, T. M. (2015). Pengertian Pemrograman C++. Dipetik Mei 16, 2018, dari https://aboutcprogramming.wordpress.com/2015/11/08/bahasa_pemrogra man_c/

[3] Anonym. (2018). DOSBox. Dipetik Mei 16, 2018, dari https://en.wikipedia.org/wiki/DOSBox

[4] Anonym. (2016). Pengertian Grafik. Dipetik May 16, 2018, dari Definisi Fungsi Jenis Grafik: http://definisipengertian.net/pengertian-grafik-definisi-fungsijenis-grafik/

[5] Anonym. (2014). Turbo C++. Dipetik 5 16, 2016, dari https://id.wikipedia.org/wiki/Turbo_C\%2B\%2B

[6] Arif, Ahmad. (2015). Rekayasa Perangkat Lunak Kriptografi Menggunakan Algoritma Advanced Ecncryption Standart(AES) 128 BIT Pada Sistem Keamanan Short Message Service (SMS) Berbasis Android. Fakultas Teknologi Industri. Institut Teknologi Padang : Padang.

[7] Choudhury, R., \& Samal, C. (2017). Target Assignment in Robotics and its Distance Optimality Using DDA Optimization in Image Processing . IJSRM INTERNATIONAL JOURNAL OF SCIENCE AND RESEARCH METHODOLOGY , 3040.

[8] Handayaningsih, S., \& Agustama, M. (2014). Media Pembelajaran Algoritma Garis dan Lingkaran Berbasis Multimedia. Jurnal Sarjana Teknik Informatika , 1051-1060.

[9] Harris. (2003). Multimedia dan Animasi. Jakarta: Elex Media.

[10] Ipte, S., Agarwal, R., Barodawala, M., Grupta, R., \& Pappu, S. (2017). Efficient Plotting Algorithm. International Journal of Advanced Research in Computer and Communication Engineering , 190-194.

[11] Khan, M. U., Beg, R., \& Khan, M. Z. (t.thn.). Improved Line Drawing Algorithm: An Approach and Proposal. UACEE International Journal of Computer Science and its Applications , 122-127.

[12] Lepank. (2012). Pengertian Grafik Menurut Para Ahli. Dipetik Mei 16, 2018, dari http://www.lepank.com/2012/08/pengertian-grafik-menurut-beberapaahli.html.

[13] Pressman, R. S. (2012). Rekayasa Perangkat Lunak. Yogyakarta: ANDI.

[14] SNI 03-2834-2000. (2000). Tata Cara Pembuatan Rencana Campuran Beton Normal. Bandung: Badan Standarisasi Nasional.

[15] SNI 03-2847-2002. (2002). Tata cara Perencanaan Struktur Beton Untuk Bangunan Gedung. Bandung: Badan Standarisasi Nasional.

[16] SNI 03-6820-2002. (2002). Spesifikasi Agregat Halus Untuk Pekerjaan Adukan dan Plesteran Dengan Bahan Semen. Bandung: Badan Standarisasi Nasional.

[17] Sukirman, S. (2003). Beton Aspal Campuran Panas. DKI Jakarta: Yayasan Obor Indonesia.

[18] Trivedi, J. (2015). Simulation of DDA (Digital Differential Analyzer) Line Generation Algorithm. IJCSN International Journal of Computer Science and Network, 110-111.

[19] Whitten et al. (2004). Developing Multimedia. Amerika: Gullif Press. 